\title{
TEXTKRITISCHE ZEICHEN
}

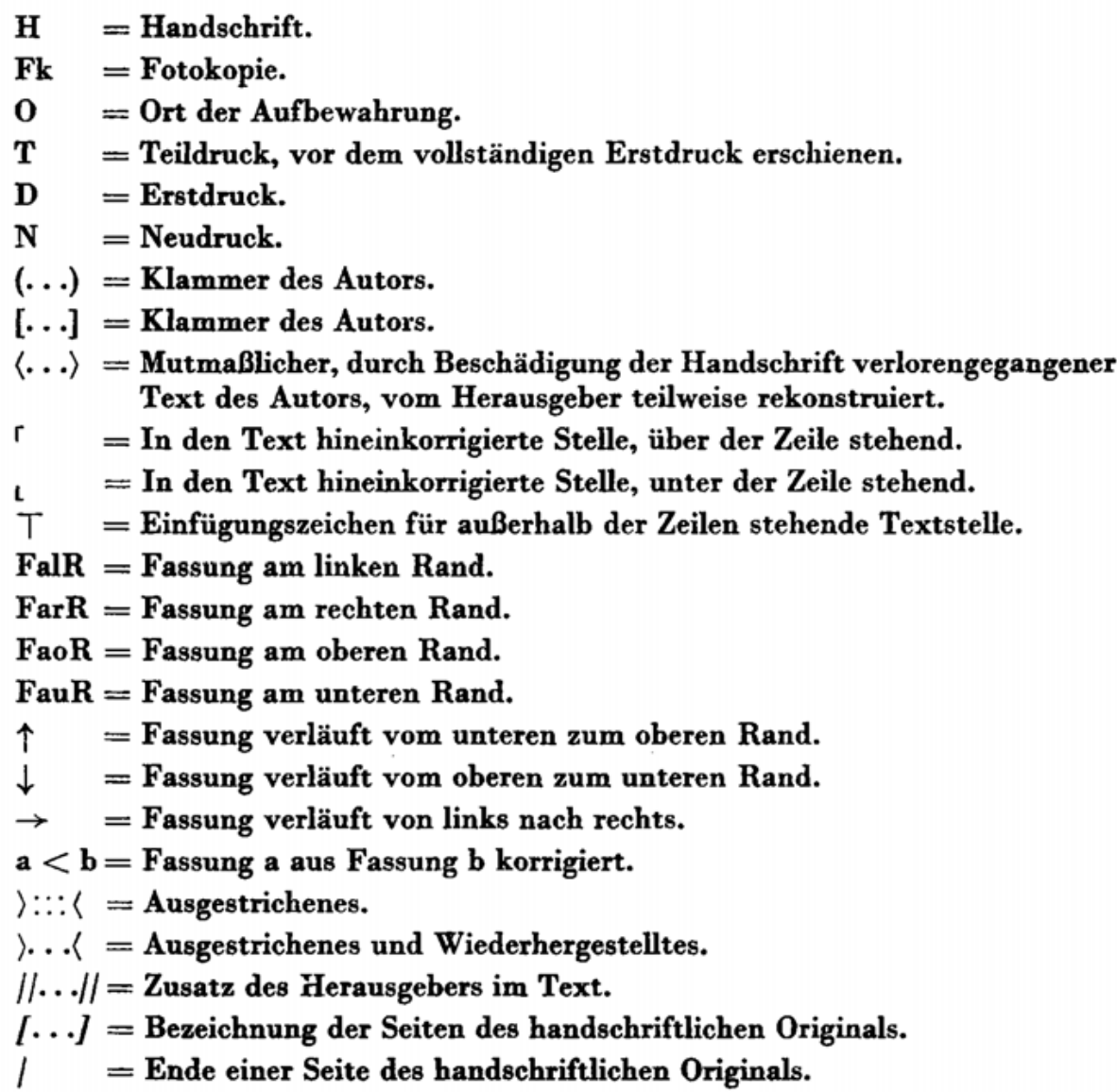


